\title{
Population biology and secondary production of the stout razor clam Tagelus plebeius (Bivalvia, Solecurtidae) on a sandflat in southeastern Brazil
}

\author{
Jolnnye R. Abrahão1, 3; Ricardo S. Cardoso2; Leonardo Q. Yokoyama' \& A. Cecilia Z. Amaral11,3 \\ ${ }^{1}$ Laboratório de Biologia Marinha, Departamento de Biologia Animal, Instituto de Biologia, Universidade Estadual de \\ Campinas. Caixa Postal 6109, 13083-970 Campinas, São Paulo, Brasil. \\ 2 Laboratório de Ecologia Marinha, Departamento de Ecologia e Recursos Marinhos, Universidade Federal do Estado do Rio \\ de Janeiro. 22290-240 Rio de Janeiro, Rio de Janeiro, Brasil. \\ ${ }_{3}^{3}$ Corresponding authors. E-mail: jolnnye@yahoo.com.br; ceamaral@unicamp.br
}

\begin{abstract}
The population biology and production of the stout razor clam Tagelus plebeius Lightfoot, 1786 were investigated on an intertidal sandflat on the southeast coast of Brazil (Enseada Beach, São Sebastião, state of São Paulo) between April 1997 and April 1998. Two rectangular sites of $50 \times 10 \mathrm{~m}$ parallel to the waterline were established, site A (upper intertidal level) and site B (middle intertidal level), where the samples were taken in an $0.5 \times 0.5 \mathrm{~m}$ quadrat. High abundances were recorded in winter and spring, with no significant differences between the sites. The high bivalve abundances were related to the presence of very fine homogeneous sediment with low salinities. Tagelus plebeius had negative allometric growth, characteristic of deep burrowers for the relationships DM/SL and AFDM/SL. Parameters of the modified von Bertalanffy growth function were: $\mathrm{L}_{\infty}=67.01 \mathrm{~mm}, \mathrm{~K}=1.73$ year $^{-1}, \mathrm{t}_{0}=-0.11$ year, $\mathrm{C}=0.43, \mathrm{WP}=0.96$. The instantaneous mortality (Z) was 3.12 year $^{-1}$, relatively high in comparison to other tropical bivalve populations. Secondary production

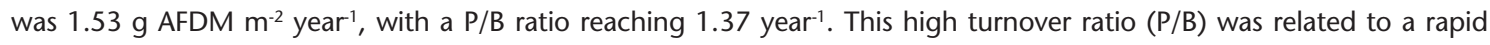
population replacement, connected with the short life span and high mortality of the species.
\end{abstract}

KEY WORDS. Abundance; growth; intertidal zone; mortality.

Traditional descriptive studies on benthic soft-bottom communities have elucidated the interactions that determine their spatial and temporal structures; however, such studies provide little information about the species (CraIg 1994). The study of the population dynamics and production and biomass of dominant species, especially bivalves, offers a better knowledge of their roles in the communities, as well as the possibility of comparisons between ecosystems (HiвBERT 1976).

Bivalves stand out for their diversity of species, numerical dominance, high biomass, and ecological importance in marine soft-bottom substrates (Ólafsson et al. 1993, URban 1994). They occur in a variety of coastal environments, including estuaries and sandy beaches, where they are exposed to different factors such as temperature, salinity, and water currents. These factors can determine their distribution, and influence growth and reproduction (Fuiman et al. 1999, CARdoso et al. 2007). Food quality and availability, tidal level, and substrate are reported to act locally on bivalve populations (Newell \& Hidu 1982, HonKoOP \& Beukema 1997, Beukema et al. 2002, Carmichael et al. 2004). Populations from low intertidal levels and subtidal areas have high growth and reproductive output because of a long submersion period, which enables higher amounts of food intake (GuevarA
\& Niell 1989, Roseberry et al. 1991, De Montaudoin 1996, Cardoso et al. 2007).

Tagelus plebeius Lightfoot, 1786 is a solecurtid bivalve, common in estuaries and intertidal zones of sandy beaches, occurring in stable sediments from the upper intertidal level to depths of approximately $10 \mathrm{~m}$, and with growth rates ranging according to the elevation above the mean low intertidal level (Chanley \& Castagna 1971, Holland \& Dean 1977a,b, Lomovaski et al. 2006). This euryhaline and suspension-feeding species builds permanent galleries (from 50 to $70 \mathrm{~cm}$ deep), and completes its pelagic cycle at a larger size than other veliger larvae (Chanley \& Castagna 1971, Arruda et al. 2003). Extant populations of $T$. plebeius are generally distributed over the Atlantic west coast from North Carolina $\left(34^{\circ} \mathrm{N}\right.$, USA) to the San Matias Gulf (41오, Argentina) (Rios 1994, Iribarne \& BotTo 1998). Tagelus plebeius is commonly used as bait in artisanal fisheries along the southeast Atlantic coast, and is exploited as a commercial fishery resource in Chile and Argentina (GutiérRez et al. 2004).

Even though $T$. plebeius has a wide distribution in the coastal region of Brazil, and is used as a fishery resource by several coastal communities, only ViéGAs (1982) analyzed the growth and secondary production of this species in an estuary 
in Maceió, and Abrahão \& Amaral (1999) described its abundance and spatial distribution in a beach on the northern coast of São Paulo. In this context, the present study aimed to analyze the population dynamics and secondary production of $T$. plebeius at an intertidal zone of a sandflat in southeast Brazil.

\section{MATERIAL AND METHODS}

Enseada Beach, located at the southern end of the Caraguatatuba Bay on the northern coast of São Paulo $\left(23^{\circ} 43^{\prime} \mathrm{S}\right.$, $\left.45^{\circ} 25^{\prime} \mathrm{W}\right)$, Brazil, is a sheltered and dissipative beach approximately $2 \mathrm{~km}$ long (OMENA \& Amaral 1997). This extensive intertidal sandflat is formed by a gentle slope $\left(1^{\circ}\right.$ to $\left.2^{\circ}\right)$, with a low tidal amplitude of less than $1 \mathrm{~m}$ (OMEna \& Amaral 2000). The upper and middle level of the intertidal region at Enseada has a sediment composed by very fine, well-sorted sand, with mean grain size ranging from 3 to $5 \phi$, low percentage of silt and clay (0.2 to $0.4 \%)$, and low organic matter content (1.3 to $1.7 \%)$ (Abrahão \& Amaral 1999, Arruda et al. 2003). A predominance of very fine and well-sorted sediments denoted the hydrodynamic stability of the study areas. In addition, the Enseada Beach is subject to anthropogenic interference because it is located near to an urban center. The freshwater influx and a waste water discharge, which flow onto the middle level of the intertidal region caused a high range of salinity and increased the amount of organic matter dissolved in the water, especially during summer.

The stout razor clams were sampled monthly between April 1997 and April 1998, during low tide, at two rectangular sites of $50 \times 10 \mathrm{~m}$, parallel to the waterline and separated by a distance of approximately $50 \mathrm{~m}$ : Site A (upper intertidal level) and Site B (middle intertidal level). Monthly, at each site, five random samples were obtained with a $0.5 \times 0.5 \mathrm{~m}^{2}$. The sediment was removed to a depth of $50 \mathrm{~cm}$ and washed through a $1.0 \mathrm{~mm}$ mesh net. Live razor clams were separated from dead clams (empty shells with the flexible ligament still attached see IrIBARNe et al. 1998). As the sediment features of sediment were determined in previous studies and considered to be homogeneous in the two sites (Abrahão \& Amaral 1999, Arruda et al. 2003), only the interstitial water salinity was measured during every sample series (five samples per month) for both sites. To increase the number of individuals for the analyses of size distribution and growth, other clams were randomly collected in areas surrounding the original sites, always taking into account the tidal level where the sites were located.

In the laboratory, the antero-posterior length of each individual (alive and dead) was measured with a digital caliper with a $0.01 \mathrm{~mm}$ precision. The soft tissues of the clams were separated from the shells and dried at $80^{\circ} \mathrm{C}$ until constant weight to obtain the dry mass (DM). The ash-free dry mass (AFDM) resulted from the loss after the soft dried tissues were incinerated at $550^{\circ} \mathrm{C}$ for five hours (Urban \& CAmpos 1994).

Cochran's test (UNDERWOOD 1997) was used to test the homogeneity of variances, and to remove any heterogeneity; data were $\log _{10} x+1$ transformed. The mean values of the parameters interstitial salinity, abundance of live clams, and abundance of dead clams were compared between the sites with a paired Student's t-test. A correlation between the interstitial salinity and the mean monthly abundance of live clams for each site was verified with the Pearson correlation coefficient. In all statistical analyses, a significance level of 5\% was adopted (ZAR 1996).

The relationships between the shell length (SL) versus dry mass (DM) and ash-free dry mass (AFDM) were defined through exponential regressions: $\mathrm{DM}=\mathrm{aSL}^{\mathrm{b}}$ and $\mathrm{AFDM}=\mathrm{aSL}^{\mathrm{b}}$, where $\mathrm{a}$ and $\mathrm{b}$ are constants. For both regressions, SL was considered the independent variable. To confirm if the values of $b$ obtained in the exponential regressions were significantly different from the isometric values $(b=3)$, a t-test $(\mathrm{Ho}, b=3)$ was applied (GASPAR et al. 2001). The mean shell lengths of T. plebeius at sites A and B were compared.

To perform the growth analysis, the monthly shell lengthfrequency distributions of live clams were used, according to procedures suggested by Gómez \& Defeo (1999) and Defeo et al. (2001). This procedure consists of: (1) separate shell length-frequency distributions using the NORMSEP routine of the FISAT statistical program (GAYANILO et al. 1996); (2) assign absolute ages for the respective cohorts (lengths) and build the relation agelength key; and (3) use the age-length results to fit the von Bertalanffy growth curve modified for seasonal oscillation in growth (VBGF: GAYANILO et al. 1996) by non-linear least-squares:

$L_{t}=L_{\infty}\left[1-e^{\left[-K\left(t-t_{0}\right)+(K C / 2 \pi) \sin 2 \pi(t-w p)-(K C / 2 \pi) \sin 2 \pi\left(t_{0}-w p\right)\right]}\right]$ where $L_{t}$ is the shell length at age $t ; L_{\infty}$ is the maximum theoretical shell length for the species; $\mathrm{K}$ is the curvature parameter; $\mathrm{C}$ is the constant of amplitude of the seasonal oscillation growth; $t_{0}$ is the theoretical age at size 0 ; and WP is the winterpoint, i.e., period of growth reduction, expressed as a decimal fraction of the year. The growth index phi-prima $\left(\phi^{\prime}\right)$, defined as: $\phi^{\prime}=2 \log _{10}\left(\mathrm{~L}_{\infty}\right)+\log _{10} \mathrm{~K}$ (Pauly \& Munro 1984, Defeo et al. 1992) was employed as a measure of overall growth performance.

The instantaneous mortality rate $(\mathrm{Z})$ was calculated by the single negative exponential model using the length-converted catch curve method (Pauly et al. 1995) provided by the FISAT program (GAYANILO et al. 1996). The estimation of $Z$ was given by: $\ln (\mathrm{N})=\mathrm{g}-\mathrm{Zt}$, where $\mathrm{N}$ is the number of individuals; $\mathrm{g}$, the regression intercept, $Z$, in module, the unbiased mortality estimated; and t, the estimated age in each cohort (Pauly et al. 1995).

Life span was estimated by the growth parameters of VBGF and on the basis of the length representing the $99^{\text {th }}$ percentile of the population, $\mathrm{L}_{99 \%}$ (CARdoso \& Veloso, 1996).

Production was estimated by the weight-specific growth rate method (CRISP 1984), given by the equation $P=\Sigma \Sigma f_{i} G_{i} W_{i} \Delta t$, where $f_{i}$ is the mean number of individuals in size class i during period $\Delta t,{ }_{G i}$ is the mass-specific growth rate in size class $i$, 
and $\Delta t$ is the time range. $G_{i}$ was obtained through the equation: $G_{i}=b K\left[\left(L_{\infty} / L_{i}\right)-1\right]$, where $b$ is the exponent of the weightlength ratio, $K$ and $L_{\infty}$ are parameters of the VBG equation, and $\mathrm{Li}$ is the mean length in size class $\mathrm{i}$. The mean annual biomass was calculated as: $\mathrm{B}=\Sigma \Sigma \mathrm{f}_{\mathrm{i}} \mathrm{W}_{\mathrm{i}} \Delta \mathrm{t}$.

\section{RESULTS}

The mean salinity at site A was $16.6 \pm 6.1$, ranging between 11.2 (October 1997) and 34.4 (July 1997). At site B the mean salinity was $5.4 \pm 1.5$, ranging from 3.6 (January 1998) to 25.4 (August 1997). Salinities were significantly different between sites ( $\mathrm{t}=4.896, \mathrm{df}=10, \mathrm{p}=0.001)$.

At site A, 831 individuals of T. plebeius were obtained: 264 alive and 567 dead. At site B, 191 live and 350 dead individuals were collected, totaling 541 clams. At the former, the highest abundance was recorded in winter (July 1997), and the lowest in autumn (May 1997) and summer (February 1998) (Fig. 1). For site B, the highest abundance was observed in spring (October 1997) and the lowest in autumn (June 1997) and the end of winter (September 1997) (Fig. 1). There was no significant difference in abundance between the two sites $(\mathrm{t}=0.839$; $\mathrm{gl}=12 ; \mathrm{p}=0.418$ ).

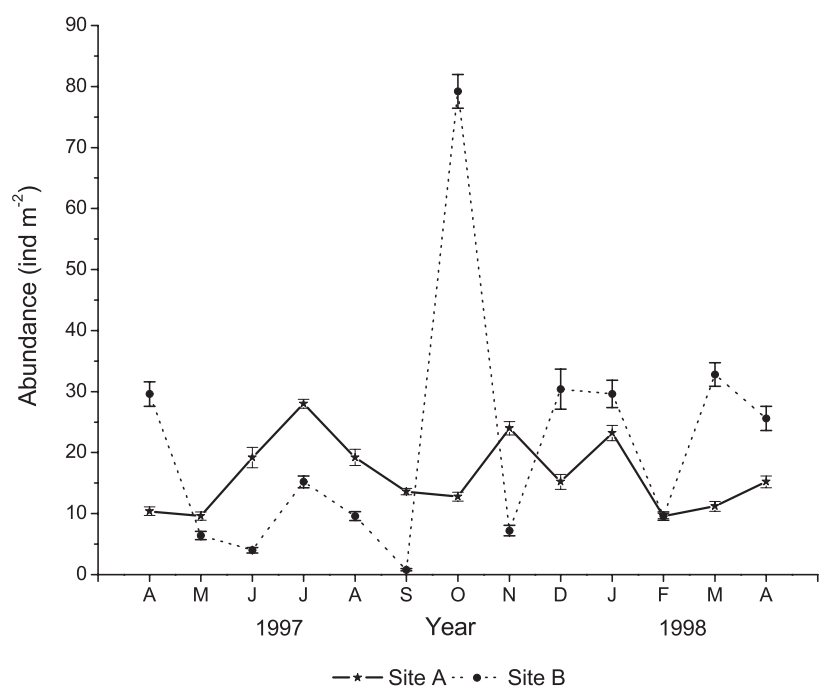

Figure 1. Tagelus plebeius. Temporal variation of abundance of live individuals (ind $\mathrm{m}^{-2}$ ). Vertical bar: standard error.

Regarding dead clams, at site A, the high and low peaks of abundances were recorded in April and June 1997, respectively. At site B, the highest abundances were observed in autumn (March and April 1998) and the lowest over the entire year. Mean annual abundances of dead clams were significantly different between the sites $(t=5.308$; $d f=12, p=0.000)$. The correlation between the number of individuals (mean abun- dance $)$ and the salinity was not significant $(\mathrm{r}=-0.050, \mathrm{p}=0.825)$.

Negative allometry was observed for the relationships $\mathrm{DM} / \mathrm{SL}$ and AFDM/SL, with the shell length increasing faster than the body mass (Tab. I).

The mean shell lengths of T. plebeius at sites A and B were $48.76 \mathrm{~mm} \pm 7.22$ and $52.02 \mathrm{~mm} \pm 9.80$, respectively. The populations at both sites were composed by similar size classes, with a dominance of adult individuals (Fig. 2). At site A, the smallest clam was $13.16 \mathrm{~mm}$ long and the maximum shell length observed was $63.19 \mathrm{~mm}$; at site B a maximum shell length of 65.97 $\mathrm{mm}$ and a minimum of $10.85 \mathrm{~mm}$ were recorded.
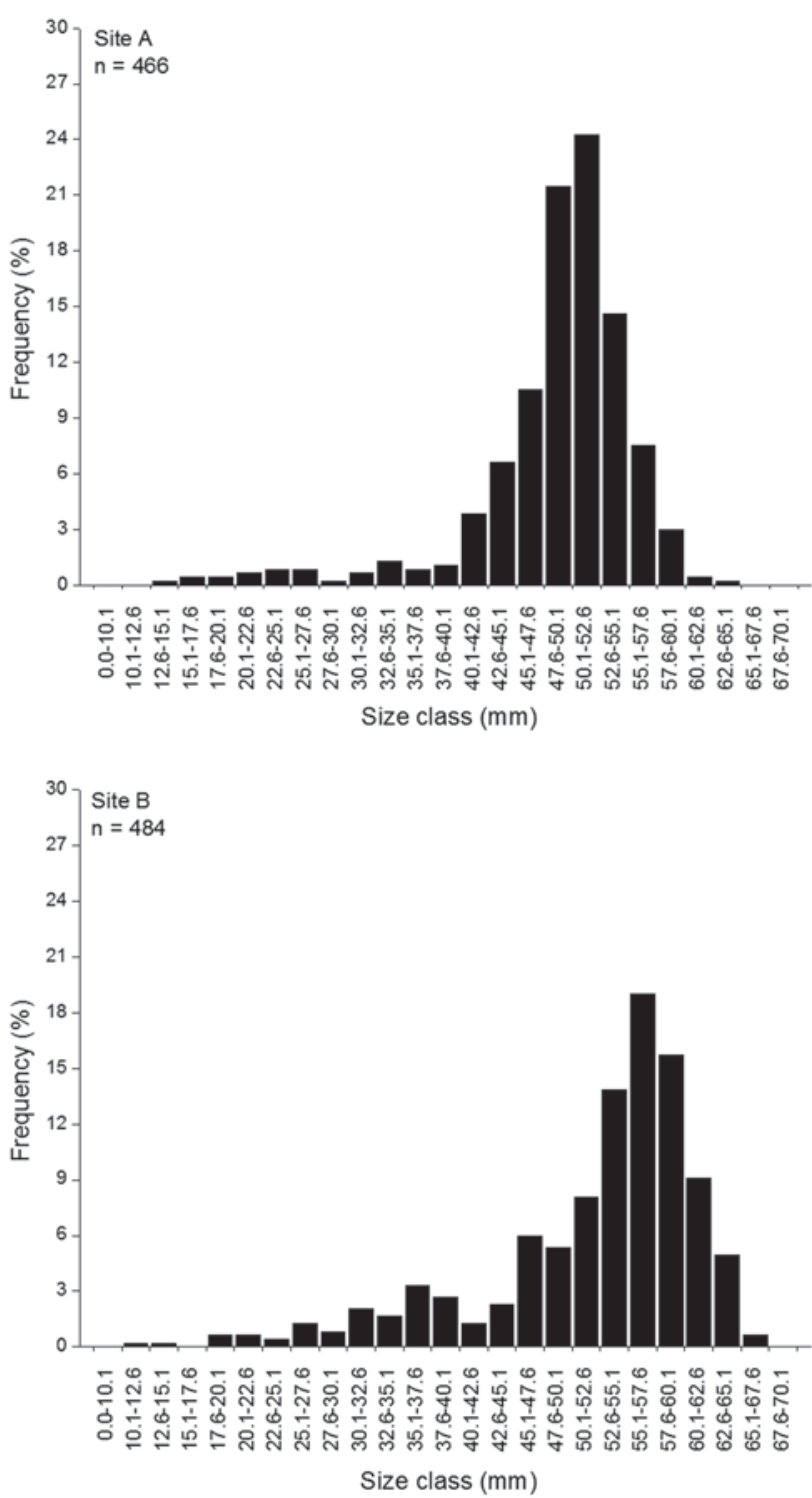

Figure 2. Tagelus plebeius. Size frequency distribution in the sites $A$ and B of Enseada Beach. 

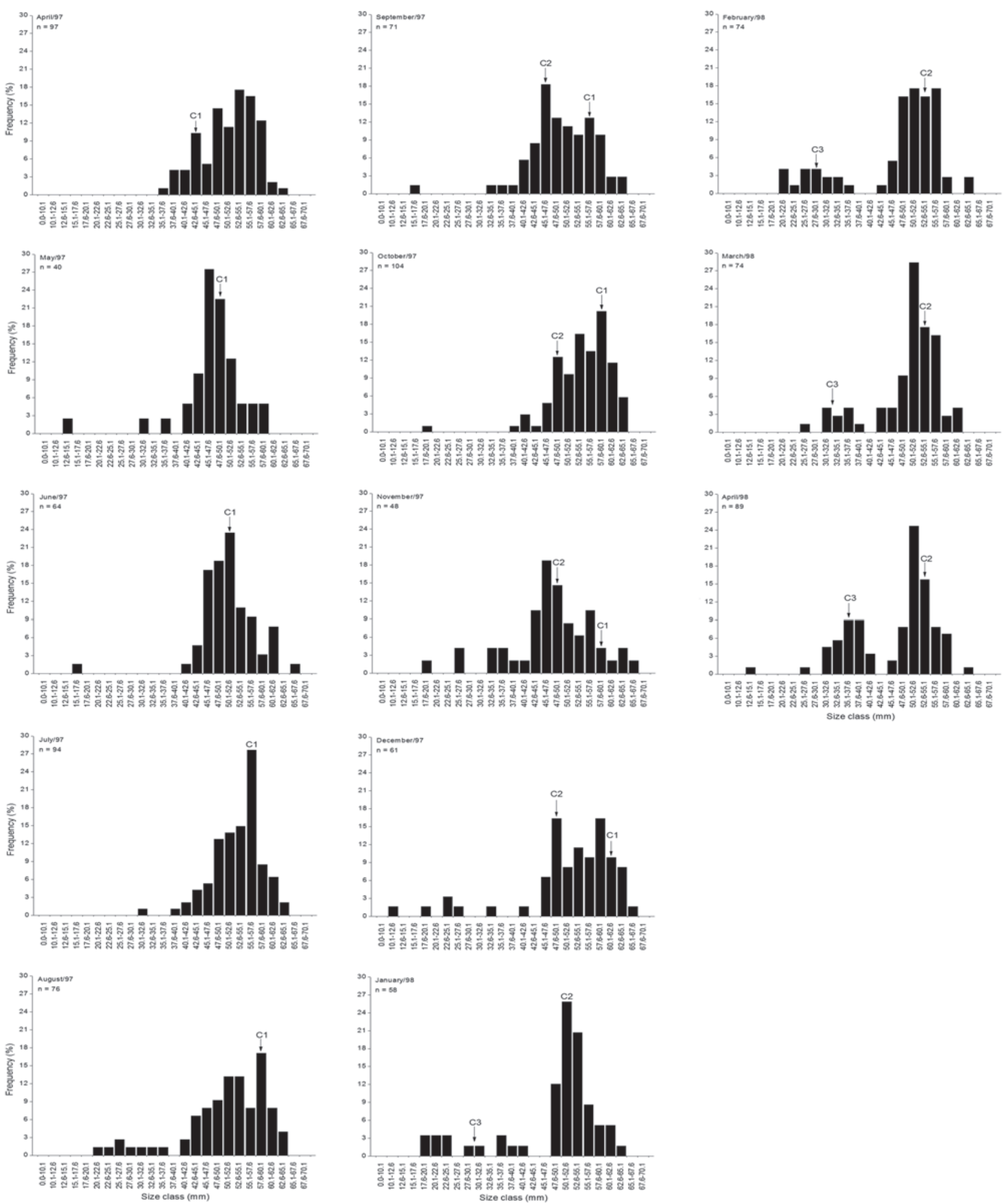

Figure 3. Tagelus plebeius. Frequency distribution of size class shell in the sites grouped in the differences months of study in the Enseada Beach. 
Table I. Tagelus plebeius. Descriptive statistics and parameters of the relation mass/length of the population of Enseada beach. ( $\mathrm{N}) \mathrm{Number}$ of individuals, $\left(r^{2}\right)$ determination coefficient, (SE of b) standard error of $b,(I C)$ range of confidence, ( $p$ ) probability.

\begin{tabular}{lcccccccc}
\hline Regression & $\mathrm{N}$ & $\mathrm{a}$ & $\mathrm{b}$ & Equation & $\mathrm{r}^{2}$ & $\mathrm{SE}$ of b (95\% IC of b) & $\mathrm{p}$ & Allometry \\
\hline $\mathrm{DM} / \mathrm{L}$ & 56 & 0.008 & 2.599 & $\mathrm{PS}=0.008 . \mathrm{CT} 2.599$ & 0.866 & $0.173(0.003-5.195)$ & $<0.001$ & Negative \\
AFDM/L & 54 & 0.005 & 2.281 & PSLC = 0.005.CT 2.281 & 0.710 & $0.248(1.372-5.934)$ & $<0.001$ & Negative \\
\hline
\end{tabular}

Three overlapping cohorts were distinguished in the sizefrequency distributions of T. plebeius (Fig. 3). The population had a unimodal distribution between May and July 1997, with cohort 1 growing continuously from size class $50.1 \mathrm{~mm}$ to high length classes over the months until January 1998, when a decrease occurred in the abundance, with few individuals represented. From September 1997, the size-frequency distribution became bimodal, represented by cohorts 1 (size class 57.6 $\mathrm{mm}$ ) and 2 (size class $47.6 \mathrm{~mm}$ ). In January 1998, the population still had a bimodal distribution, with the displacement of the mode, now of cohort $2(52.6 \mathrm{~mm})$, and a new mode represented by cohort $3(30.1 \mathrm{~mm})$.

The growth analysis revealed an asymptotic size of 67.01 $\mathrm{mm}$ for T. plebeius. The estimate of growth parameters was significant ( $\mathrm{p}<0.001$, Tab. II), except for $C$ and $t_{0}$. The clams grew rapidly in their first years, reflected by the annual growth rate $\left(\mathrm{K}=1.73\right.$ year $\left.^{-1}\right)$, with the rate declining as they approached the asymptotic size (Fig. 4). The "winter point" (WP) indicated a decrease in growth by the end of October $1997(0.9 \times 12=$ 10.8 months). Although not significant, parameter $\mathrm{C}$ indicated a small oscillation in growth (Tab. II, Fig. 4). The growth intensity $\left(\phi^{\prime}\right)$ was 3.89 . Life expectancy on the basis of $\mathrm{L}_{99 \%}$ was 19 months, and the life span of the largest individuals found

Table II. Tagelus plebeius. Growth parameters estimated by the seasonal modified version of the von Bertalanffy growth function. $\left(L_{\infty}\right)$ Asymptotic length; (K) curvature parameter; (C) constant for the amplitude of seasonal oscillation of growth; $\left(\mathrm{t}_{\mathrm{o}}\right)$ theoretical age at length 0 ; (WP) winter-point: point of lowest growth rate in the year; $\left(r^{2}\right)$ determination coefficient; $(\phi)$ standard growth index; $\left(\mathrm{L}_{99 \%}\right)$ length representing $99 \%$ of the population and used to estimate life span.

\begin{tabular}{lcccc}
\hline \multicolumn{1}{c}{ Parameter } & Mean & $(\mathrm{SE})$ & $\mathrm{t}(26)$ & $\mathrm{p}$ \\
\hline $\mathrm{L}_{\infty}(\mathrm{mm})$ & 67.01348 & 3.93575 & 17.02687 & 0.00000 \\
$\mathrm{~K}\left(\right.$ year $\left.^{-1}\right)$ & 1.73122 & 0.37549 & 4.61053 & 0.00009 \\
$\mathrm{C}$ & 0.42889 & 0.17913 & 2.39426 & 0.24157 \\
$\mathrm{t}_{\mathrm{o}}$ (year) & -0.11908 & 0.09375 & -1.27026 & 0.21524 \\
WP & 0.96870 & 0.05633 & 17.19572 & 0.00000 \\
$\mathrm{r}^{2}$ & 0.99123 & & & \\
$\phi$ & 3.89 & & & \\
Largest $(\mathrm{mm})$ & 65.97 & & & \\
$\mathrm{~L}_{99 \%}(\mathrm{~mm})$ & 64.45 & & & \\
\hline
\end{tabular}

(65.97 mm) was estimated as 27 months. The instantaneous mortality rate (Z) calculated for T. plebeius was 3.12 year $^{-1}$.

The mean monthly density of the population of T. plebeius in Enseada Beach ranged between 16.00 and 41.60 ind. $\mathrm{m}^{-2}$, representing a mean annual biomass of $1.12 \mathrm{~g} \mathrm{AFDM} \mathrm{m}^{-2}$. The highest value of biomass was recorded in October 1997 (1.90 g AFDM $\mathrm{m}^{-2}$ ). The production ranged between $0.08 \mathrm{~g}$ and $0.21 \mathrm{~g}$ AFDM m-2 year $^{-1}$, with total production of $1.53 \mathrm{~g} \mathrm{AFDM} \mathrm{m}^{-2}$ year ${ }^{-1}$, giving a $\mathrm{P} / \mathrm{B}$ ratio of 1.37 year $^{-1}$.

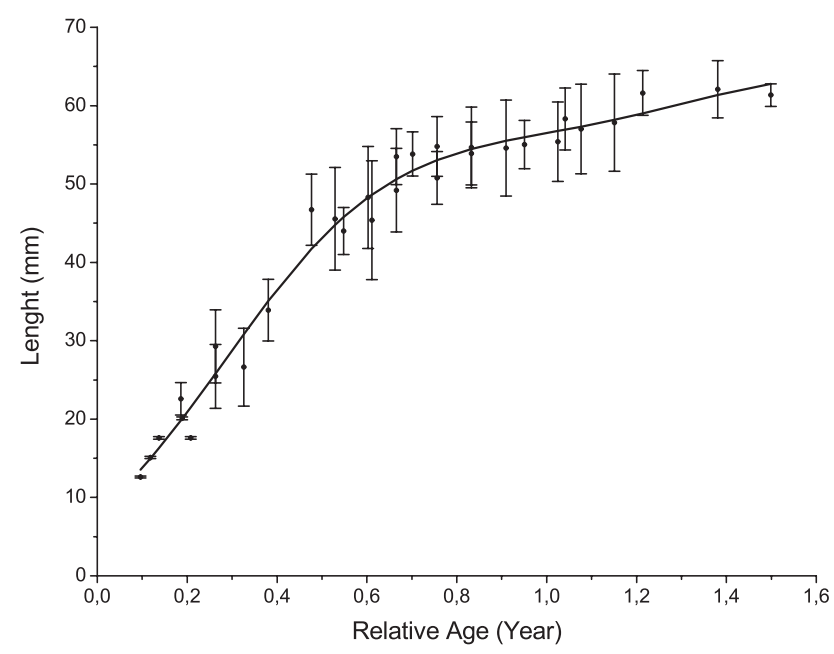

Figure 4. Tagelus plebeius. VBG growth curve with seasonal oscillation. The bars represent the standard error of the mean.

\section{DISCUSSION}

The abundances of live individuals of T. plebeius in the population at Enseada Beach showed significant fluctuations over the months of sampling. The maximum density reached 79 ind $\mathrm{m}^{-2}$. Abundances reported for other extant populations are much higher: up to 300 ind $\mathrm{m}^{-2}$ in estuaries along the northwestern Atlantic and the Gulf of Mexico (Chanley \& Castagna 1971); 138 ind $\mathrm{m}^{-2}$ in an estuary in Maceió, Brazil (O. Viégas pers. comm.); 128 ind $\mathrm{m}^{-2}$ in Florida, USA (SHERIDAN \& LIVINGSTON 1983); and up to 200 ind $\mathrm{m}^{-2}$ in the Mar Chiquita lagoon, Argentina (IRIBARNe et al. 1998). However, these high abundances were not found in other populations. The maximum mean density recorded by Holland \& DeAn (1977b) was 72 ind $\mathrm{m}^{-2}$. 
There is thus a wide range of abundance between the populations studied, regardless of latitude.

The sediment composition is very important for the distribution and abundance of T. plebeius. Holland \& Dean (1997a, b) observed that the species only occurred in sediments with grain diameter ranging from 2 to over $6 \phi$ and that high abundances were observed in areas where the sediments were composed of at least $2 \%$ silt and clay. The grain diameter, ranging from 3 to over $5 \phi$ and the low percentage of silt and clay in the sediment of Enseada Beach (AвRAHão \& AMARAL 1999), characterized the upper and middle levels as more suitable habitats for T. plebeius. The lower level is less stable and undergoes regular alterations caused by the constant deposition of sand, forming small temporary beds and impeding the development of the species.

The abundance of the trophic group SDS (suspension feeding, restricted mobility, inhalant siphon, and ctenidium) in Enseada Beach is related to the presence of very fine homogeneous sediment and low salinities (ARRUDA et al. 2003). The correlation between the SDS group and low salinities may be a factor in the high abundance of T. plebeius, a suspension-feeding bivalve, in Enseada Beach. The middle level of this beach receives domestic sewage discharge, reducing the salinity and increasing the suspended organic-matter content. According to LimA et al. (2000), great variations in salinity have a strong effect on the population dynamics of Mesodesma mactroides Deshayes, 1854. Defeo (1993) observed that an intense freshwater discharge from the Andreoni Channel (Uruguay) was responsible for the reduction in the density of adult individuals of M. mactroides.

There was no correlation between the abundance of $T$. plebeius and salinity. Although there was no mention of an optimal condition for the survivorship of the species, CASTAGNA \& Chanley (1973) reported that feeding and burrowing activities were reduced in salinities below 10, with low survivorship between salinities of 2.5 and 5.0. The temporal fluctuation in abundance may be associated with biological factors such as recruitment, mortality, and intra- and interspecific competition. High abundances of T. plebeius in South Carolina (USA) were observed in conjunction with the spring recruitment (HoLLAND \& DEAN 1977b). These authors observed that recruitment occurred mainly in low areas of the intertidal zone because of environmental and biological factors such as: enhanced physiological stress, predation by birds and other animals after larval settlement, and selective larval settlement pattern determined by the adult population. Viégas (pers. comm.) reported an inverse situation, with recruitment marked by a high abundance of juveniles in the permanently exposed area. The high recruitment in this area compared to the submerged area may result from the elimination of the larvae by the dense populations of adult T. plebeius and other filtering bivalves. Lima et al. (2000) observed an interaction between individuals of the population of $M$. mactroides, where adults reduced recruitment by passive filtration of their own larvae.
Other climatic and biotic factors besides salinity could affect the abundance of this species in Enseada Beach. No significant variations were observed in the abundance of live clams between the sites; however, the same was not observed for the dead clams. Site A showed a high number of dead clams, related to the occurrence of an increased desiccation rate in the upper level. The small numbers of dead clams found at site $\mathrm{B}$, adjacent to a stream, indicate that this is a suitable area for the development of the species, because of the low desiccation rate and high food availability. Besides the reduced salinity, which might affect the feeding activities of the clams, individuals with a large mean size were dominant at site B. Only in October 1997, and February and March 1998 was an increase in the number of dead clams observed. Coarse sediment transported in by rainfall may have increased the instability of the substrate and consequently compromised the integrity of the clams' siphon tubes, interfering with their feeding.

In this study, T. plebeius showed a negative allometry for the relationships DM/SL and AFDM/SL, which differed from the isometric growth for DM/SL observed in the South Carolina populations (HolLAND \& DEAN 1977b). LOMOVASKI et al. (2006) found negative allometry for the height/length (H/SL) and width/length (W/SL) relationships of T. plebeius. GASPAR et al. (2002) reported discrepancies in the allometric relationships of Pharus legumen Linnaeus, 1758 (Bivalvia, Solecurtidae), which, in spite of being considered a great burrower, displays negative allometry for H/SL and is isometric for W/SL. The differences in relative growth observed in T. plebeius may be related to particular ecological characteristics of the species in each environment. GASPAR et al. (2002) stated that the differences observed in the relative growth of $P$. legumen are a result of the ecological characteristics of the species, which showed a wide depth distribution in the study area. Discordance in the morphometric relationships may be a consequence of distinctive hydrological and sedimentological patterns between the areas (GASPAR et al. 2002). The sediment characteristics found at Enseada Beach (see AвraHÃo \& AMARAL 1999) were similar to those recorded by Holland \& DeAn (1977a), and relative growth could be influenced by other abiotic factors, such as salinity.

The negative allometry detected for T. plebeius reveals a morphological adaptation found in deep burrowers, which normally possess elongated shells. URBAN (1994) verified this relationship for Tagelus dombeii Lamarck, 1818. Elongated-shelled bivalves normally predominate in compact sediments because of their high capacity to burrow (EAGAR 1978), expending less energy (TRueman 1966, Stanley 1970). The long thin shells of deep burrowers could be an advantage because less energy is invested in shell growth (URBAN 1994). Species of the family Solecurtidae can burrow at least $50 \mathrm{~cm}$ in the substrate (FARINATI et al. 1992), as also observed by ABRAHÃo \& AMARAL (1999) and ARRUDA et al. (2003).

The population of $T$. plebeius showed three annual merging cohorts. January 1998 was the single period with a four age-class structure in Enseada Beach. Two recruitment peaks 
were recorded, one at the end of winter and beginning of spring (September 1997), and another in summer (February 1998). The pattern of three annual cohorts was similar to the age structure observed by Holland \& Dean (1977b); however, the authors observed the formation of four age classes in the area below the low intertidal level, and assumed that the absence of human exploitation was the main cause for it.

The asymptotic size of T. plebeius $(67.01 \mathrm{~mm})$ is larger than the values estimated by Holland \& DeAn (1977b), $65 \mathrm{~mm}$, and VIÉGAS (1982), $51.73 \mathrm{~mm}$. However, it is smaller than that estimated for T. dombeii (URBAN 1996), $88.50 \mathrm{~mm}$ (Tab. III). Ensis siliqua Linnaeus, 1758 had different values of $\mathrm{L}_{\infty}$ between populations in the United Kingdom (HENDERson \& Richardson 1994), Portugal (GASPAR et al. 1994) and Ireland (FAHY \& GAFFNEY 2001). Differences in the growth rates of some bivalves might be related to the structure of the sediment (HENDERson \& RicHARDSON 1994), thus influencing $\mathrm{L}_{\infty}$ Ensis ensis Linnaeus, 1758 had a smaller size than E. siquila; the former occurs in fine sediments and the latter in coarse sediments (HENDERSON \& RICHARDSON 1994). Furthermore, high organic-matter content and fine sediments reflect a high stability of the substrate (GRANT \& DABORN 1994), and such conditions would enhance growth and body condition for suspension-feeding bivalves (LOMOVASKy et al. 2006). Similarly, a positive influence on the population of T. plebeius, which lives in fine sediments in Enseada Beach, is expected.

The availability of food and other resources can affect the physiological costs and also influence the maximum size of bivalves. Regarding abiotic conditions, temperature seems to be the effective controlling factor (BACHELET 1980). However, differences in feeding conditions over the area of distribution can be more important than temperature (CARDOso et al. 2007). These authors observed that feeding conditions for Macoma balthica Linnaeus, 1758 of similar age classes were more favorable in areas below the low-tide level. In these locations, shell growth was rapid because individuals were continuously submersed, in contrast with those in the intertidal zone. In other bivalves such as scallops, mussels, and oysters, the growth rate also seems to be controlled by food availability (Bayne \& Worral 1980, Borrero 1987, Navarro et al. 2000, Paterson et al. 2003).

Clams at Site B showed a greater mean length $(52.02 \mathrm{~mm})$ than clams at Site A (mean length $48.58 \mathrm{~mm}$ ). This difference might be related to high availability of food at Site B, since the constant influx from a stream maintains a high feeding activity; and the domestic sewage discharge furnished a high organicmatter input. By contrast, at Site A, the physiological stress from extended periods of air exposure and the impossibility of frequent feeding seem to have reduced the growth rate.

The maximum length recorded at Enseada $(65.97 \mathrm{~mm})$ was smaller than the maximum lengths reported for other localities: 70 and $91 \mathrm{~mm}$ in South Carolina (Holland \& DeAn 1977b) and $69 \mathrm{~mm}$ at Maceió (VIÉGAS 1982). Individuals of T. plebeius are capable of attaining $50 \mathrm{~mm}$ in eight months with the estimated growth rate $\left(K=1.73\right.$ year $\left.^{-1}\right)$. Holland \& DeAn $(1977 b)$

Table III. Latitudinal variation in growth performance and mortality of different bivalves species. (K) Curvature parameter, $\left(\mathrm{L}_{\curvearrowright}\right)$ asymptotic length, $\left(\phi^{\prime}\right)$ standard growth index, $(Z)$ mortality rate.

\begin{tabular}{|c|c|c|c|c|c|c|}
\hline Species & $\mathrm{K}\left(\mathrm{yr}^{-1}\right)$ & $\mathrm{L}_{\infty}(\mathrm{mm})$ & $\phi^{\prime}$ & $\mathrm{Z}\left(\mathrm{yr}^{-1}\right)$ & Climate area & Source \\
\hline Tagelus plebeius & 1.73 & 67.01 & 3.89 & 3.12 & Subtropical $\left(23^{\circ} 43^{\prime} S\right)$ & Present study \\
\hline Gari solida & 1.34 & 57.90 & 3.65 & 1.45 & Tropical $\left(14^{\circ} 15^{\prime} \mathrm{S}\right)$ & URBAN \& TARAZONA (1996) \\
\hline Gari solida & 0.67 & 77.50 & 3.60 & 1.64 & Tropical $\left(14^{\circ} 15^{\prime} \mathrm{S}\right)$ & URBAN \& TARAZONA (1996) \\
\hline Gari solida & 0.49 & 101.60 & 3.74 & 1.18 & Tropical $\left(14^{\circ} 15^{\prime} \mathrm{S}\right)$ & URBAN \& TARAZONA (1996) \\
\hline Gari solida & 0.35 & 101.60 & 3.55 & 1.30 & Tropical $\left(14^{\circ} 15^{\prime} \mathrm{S}\right)$ & URBAN \& TARAZONA (1996) \\
\hline Donax hanleyanus & 0.90 & 28.50 & 2.86 & 1.55 & Tropical $\left(23^{\circ} 03^{\prime} \mathrm{S}\right)$ & Cardoso \& Veloso (2003) \\
\hline Donax hanleyanus & 0.80 & 26.40 & 2.75 & 1.70 & Tropical $\left(23^{\circ} 03^{\prime} \mathrm{S}\right)$ & Cardoso \& Veloso (2003) \\
\hline Tagelus dombeii & 0.23 & 88.50 & 3.26 & 0.84 & Temperate $\left(36^{\circ} \mathrm{S}\right)$ & URBAN (1996) \\
\hline Venus antique & 0.22 & 73.90 & 3.08 & 1.08 & Temperate $\left(36^{\circ} \mathrm{S}\right)$ & URBAN (1996) \\
\hline Ensis macha & 0.21 & 189.90 & 3.88 & 1.09 & Temperate $\left(36^{\circ} \mathrm{S}\right)$ & URBAN (1996) \\
\hline Gari solida & 0.31 & 89.60 & 3.39 & 0.85 & Temperate $\left(36^{\circ} 32^{\prime} \mathrm{S}\right)$ & URBAN \& CAMPOS (1994) \\
\hline Semele solida & 0.29 & 78.00 & 3.26 & 0.92 & Temperate $\left(36^{\circ} 32^{\prime} \mathrm{S}\right)$ & URBAN \& CAMPOS (1994) \\
\hline Prototacha thaca & 0.17 & 82.20 & 3.07 & 0.63 & Temperate $\left(36^{\circ} 32^{\prime} \mathrm{S}\right)$ & URBAN \& CAMPOS (1994) \\
\hline Venus antiqua & 0.18 & 80.00 & 3.06 & 0.66 & Temperate $\left(43^{\circ} 07^{\prime} \mathrm{S}\right)$ & CLASING et al. (1994) \\
\hline Ensis siliqua & 0.26 & 178.20 & 3.91 & - & Temperate $\left(53^{\circ} 08^{\prime} \mathrm{N}\right)$ & FAHY \& GAFFNEY (2001) \\
\hline Ensis siliqua & 0.53 & 154.70 & 4.10 & - & Temperate $\left(53^{\circ} 08^{\prime} \mathrm{N}\right)$ & HeNDERSON \& RichaRDSON (1994) \\
\hline Ensis ensis & 0.56 & 131.60 & 3.99 & - & Temperate $\left(53^{\circ} 17^{\prime} \mathrm{N}\right)$ & HENDERSON \& RichaRdSON (1994) \\
\hline
\end{tabular}


reported that individuals attain a shell length of approximately $50 \mathrm{~mm}$ in seven months, and VIÉGAS (1982) reported a similar size within a period of 12 months. In the latter case, intraspecific competition was the main factor affecting the growth of the clams. The homogeneity in the granulometric composition of Enseada Beach reported by AвRAHÃo \& AMARAL (1999) would enhance the growth of the clams in the studied area.

The value of $\mathrm{K}$ (1.73 year-1) for T. plebeius was high compared to some of the values determined by VIÉGAS (1982: 0.25 year $\left.^{-1}\right)$ for the same species, and by URban (1996) for $T$. dombeii $\left(0.23\right.$ year $\left.^{-1}\right)$ (Tab. III). These differences could be a result of the differing latitudinal gradients, physiological levels of tolerance of each species for different environmental conditions, and methods used to calculate growth. Growth performance can be best compared using the index of growth $\left(\phi^{\prime}\right)$, especially in bivalves (VAKILY 1992). The index for T. plebeius was estimated as 3.89 , and 2.83 (VIÉGAS 1982), and 3.26 for T. dombeii (URBAN 1996). According to VAKILY (1992), bivalves grow faster in low latitudes because the higher temperatures increase their metabolic rates. Furthermore, there is evidence that growth rates of bivalves that inhabit the intertidal zone decrease with the reduction of immersion time (GILlmor 1982, Peterson \& Black 1988, LOMOVASKY et al. 2006).

The $Z$ value obtained in this study was higher than the values obtained for the majority of bivalves, especially in temperate regions (Tab. III). This high value is explained by the large numbers of individuals found dead in the sediment, a consequence of the presence of large numbers of predators, especially birds, during low-tide periods. According to ABRAHão
\& AMARAL (1999) the presence of predators such as hawks, vultures, sandpipers, and crustaceans could be responsible for the population mortality of T. plebeius. IRIBARNe et al. (1998) reported that the American oystercatcher Haematopus palliatus Temminck, 1820 was an important source of T. plebeius mortality in Argentinean estuaries. Similar conditions were observed for T. dombeii in the tidal flat of Corhuín, Chile (LARDies et al. 2001). No individuals of $M$. balthica over five years old were observed in the intertidal areas, reflecting the high mortality of adults predated upon by birds (CARDoso et al. 2007).

Mortality rate can also be related to the human exploitation of clams, which are collected for food at Enseada Beach (Abrahão \& Amaral 1999). Clasing et al. (1994) found that the increased mortality of Venus antiqua King \& Broderip, 1832 in Chile was the result of intense human exploitation of the natural beds. In conjunction with the intense exploitation, the physical stress caused by sediment disturbance during harvesting changes the substrate penetrability and decreases larval settlement. This restricts the burrowing movements of $T$. plebeius and may increase mortality. Defeo \& de Alava (1995) and DEFeo (1998) made similar observations in for another species, M. mactroides.

The estimated value of secondary production for $T$. plebeius was $1.53 \mathrm{~g} \mathrm{AFDM} \mathrm{m}^{-2}$ year $^{-1}$, lower than the values observed for the same species by VIÉGAS (1982), (2.19 g AFDM m ${ }^{2}$ year $\left.^{-1}\right)$, and for T. dombeii by Urban (1996), (7.8 AFDM m² year $\left.{ }^{-1}\right)$.However, the population of $T$. plebeius at Enseada Beach showed a high $\mathrm{P} / \mathrm{B}$ ratio compared to the former populations (Tab. IV).

Table IV. Comparison of secondary production $\left(\mathrm{P}, \mathrm{g} \mathrm{AFDM} \mathrm{m}^{-2}\right.$ year $\left.{ }^{-1}\right)$ and production-to-biomass $(\mathrm{P} /)$ ratio of several bivalves species from different geographical regions.

\begin{tabular}{|c|c|c|c|c|}
\hline Species & $P$ & $\mathrm{P} / \mathrm{B}$ & Climate area & Source \\
\hline Tagelus plebeius & 1.53 & 1.37 & Subtropical $\left(23^{\circ} 43^{\prime} S\right)$ & Present study \\
\hline Tagelus plebeius & 2.19 & 1.23 & Tropical $\left(9^{\circ} 37^{\prime} \mathrm{S}\right)$ & VIÉGAS (1982) \\
\hline Donax serra & 273.20 & 1.60 & Tropical $\left(22^{\circ} 47^{\prime} S\right)$ & Laudien et al. (2003) \\
\hline Donax serra & 356.60 & 1.20 & Tropical $\left(22^{\circ} 47^{\prime} S\right)$ & LAUdien et al. (2003) \\
\hline Donax serra & 166.90 & 1.20 & Tropical $\left(22^{\circ} 59^{\prime} \mathrm{S}\right)$ & LAUdien et al. (2003) \\
\hline Donax serra & 637.30 & 1.20 & Tropical $\left(22^{\circ} 59^{\prime} S\right)$ & Laudien et al. (2003) \\
\hline Donax hanleyanus & 0.76 & 1.59 & Tropical $\left(23^{\circ} 03^{\prime} \mathrm{S}\right)$ & Cardoso \& Veloso (2003) \\
\hline Donax hanleyanus & 3.67 & 1.45 & Tropical $\left(23^{\circ} 03^{\prime} \mathrm{S}\right)$ & Cardoso \& Veloso (2003) \\
\hline Ensis macha & 9.70 & 0.22 & Temperate $\left(36^{\circ} \mathrm{S}\right)$ & URBAN (1996) \\
\hline Tagelus dombeii & 7.80 & 0.29 & Temperate $\left(36^{\circ} \mathrm{S}\right)$ & URBAN (1996) \\
\hline Venus antiqua & 22.00 & 0.18 & Temperate $\left(36^{\circ} \mathrm{S}\right)$ & URBAN (1996) \\
\hline Gari solida & 27.60 & 0.33 & Temperate $\left(36^{\circ} 32^{\prime} \mathrm{S}\right)$ & URBAN \& CAMPOS (1994) \\
\hline Prototacha thaca & 16.90 & 0.27 & Temperate $\left(36^{\circ} 32^{\prime} S\right)$ & URBAN \& CAMPOS (1994) \\
\hline Semele solida & 4.80 & 0.19 & Temperate $\left(36^{\circ} 32^{\prime} \mathrm{S}\right)$ & URBAN \& CAMPOS (1994) \\
\hline Venus antiqua & 42.00 & 0.57 & Temperate $\left(43^{\circ} 07^{\prime} S\right)$ & CLASING et al. (1994) \\
\hline
\end{tabular}


A pattern of turnover ( $\mathrm{P} / \mathrm{B}$ ratio) increase from temperate to tropical regions is evident when ratios from different geographical regions are compared (Tab. IV). However, this does not apply to all species and systems. Cardoso \& Veloso (2003) observed that the wide range of production and biomass between species of Donax resulted from the influence of a latitudinal temperature gradient and food availability. High somatic production of Venus antiqua was associated with an extended period of primary production in Yaldad Bay, Chile (Clasing et al. 1994). Upwelling was responsible for high production of Donax serra Röding, 1798 on the Namibian coast (Africa), increasing the nutrients in the water and favoring growth (LAUDIEN et al. 2003). The high $\mathrm{P} / \mathrm{B}$ estimated for T. plebeius at Enseada may be related to high food availability and organic matter supplied by domestic-sewage discharge.

The productivity of a population can vary because of oscillations in its density and size structure (recruitment periods), as well as other intrinsic characteristics (growth) (CAETANo et al. 2006). Populations with a high $\mathrm{P} / \mathrm{B}$ ratio are composed of small individuals with rapid growth and short life span, whereas low values of $\mathrm{P} / \mathrm{B}$ are associated with large individuals, low growth rate, and long life span (CARdoso \& Veloso 2003). The low P/B ratios recorded for Gari solida Gray, 1828, Semele solida Gray, 1828, and Protothaca thaca Molina, 1782 in the Bay of Dichato (Chile) resulted from the small number of recruits, producing populations of old individuals with low secondary production (Urban \& Campos 1994). Cardoso \& Veloso (2003) reported that the elevated production of Donax hanleyanus Phillipi, 1845 at Restinga da Marambaia Beach (Brazil) was associated with high densities. URban \& CAMPos (1994) observed that the difference in $\mathrm{P} / \mathrm{B}$ ratios between populations of $V$. antiqua in two regions of Chile was caused by different rates of exploitation at fishery sites. High mortality induced by human exploitation was responsible for the high $\mathrm{P} / \mathrm{B}$ ratio of $V$. antiqua in comparison to other species of the superfamily Veneracea (CLAsing et al. 1994).

Tagelus plebeius showed a P/B ratio typical of highly productive environments, attributed to high levels of organic matter from domestic-sewage discharge at Enseada Beach, which is not an estuarine region. Furthermore, this high $\mathrm{P} / \mathrm{B}$ ratio may also be a consequence of rapid population replacement together with a short life span (27 months) and high mortality rate. Part of the secondary production by this clam is consumed by crabs, fish, and especially birds (ABRAHão \& AMARAL 1999), and may constitute an important food resource for human populations. The present results have shown that $T$. plebeius is an essential trophic link in this coastal ecosystem.

\section{ACKNOWLEDGMENTS}

This study is part of the extensive program "Environmental Monitoring of Sandy Beach Fauna of São Sebastião Channel", which could not have been completed without the collaboration of a team of students, technicians, and colleagues. We thank Alexander Turra and Márcia Denadai for their assis- tance in data analysis. We also thank to anonymous referees for valuable comments on the manuscripts. Thanks also to J.W. Reid for revision of the English text. We express our sincere thanks to E. Soares Marinho, A. Máximo Rosa, and the CEBIMar technicians who assisted in the field work. We are also grateful to the Centro de Biologia Marinha (CEBIMar-USP), and IB/ UNICAMP for their assistance with logistics. Financial support for this study was provided by CNPq and FAEPEX-UNICAMP.

\section{LITERATURE CITED}

Abrahão, J.R. \& A.C.Z Amaral. 1999. Tamanho, densidade e distibuição de Tagelus plebeius (Veneroida, Psammobiidae) em uma praia arenosa, São Paulo, Brasil. Iheringia, Série Zoologia, 87: 181-189.

Arruda, E.P.; O. Domaneschi \& A.C.Z. Amaral. 2003. Molluscs feeding guilds on sand beaches in São Paulo state, Brazil. Marine Biology 143: 691-701.

BACHelet, G. 1980. Growth and recruitment of the tellinid bivalve Macoma balthica, at the southern limit of its geographical distribution, the Gironde estuary (SW France). Marine Biology 59: 105-117.

BAYNe, B.L. \& C.M. WorRAL. 1980. Growth and reproductions of mussels Mytilus edulis from two populations. Marine Biology 3: 317-328.

Beukema, J.J.; G.C. Cadée \& R. DekKer. 2002. Zoobenthic biomass limited by phytoplankton abundance: evidence from parallel changes in two long-term data series in, the Wadden Sea. Journal of Sea Research 48: 111-125.

Borrero, F.J. 1987. Tidal height and gametogenesis reproductive variation among populations of Geukensia demissa. Biological Bulletin 173: 160-1168.

Caetano, C.H.S.; R.S. Cardooso; V.G. Veloso \& E.S. Silva. 2006. Population biology and secondary production of Excirolana braziliensis (Isopoda: Cirolanidae) in two sandy beaches of southeastern Brazil. Journal of Coastal Research 22 (4): 825-835.

Cardoso, J.F.M.F.; J.I.J WitTe \& H.W. van der VeER. 2007. Habitat related growth and reproductive investment in estuarine waters, illustrated for the tellinid bivalve Macoma balthica (L.) in the western Dutch Wadden Sea. Marine Biology 152: 1271-1282.

Cardoso, R.S. \& V.G. Veloso. 1996. Population biology and secondary production of the sandhopper Pseudorchestoidea brasiliensis (Amphipoda: Talitridae) at Prainha beach, Brazil. Marine Ecology Progress Series 142: 111-119.

Cardoso, R.S. \& V.G. Veloso. 2003. Population dynamics and secondary production of the wedge clam Donax hanleyanus (Bivalvia: Donacidae) on a high-energy, subtropical beach of Brazil. Marine Biology 142 (1): 153-162.

Carmichael, R.H.; A.C. Shriver \& I. Valiela. 2004. Changes in shell and soft tissue growth, tissue composition, and survival of quahogs, Mercenaria mercenaria, and softshell clams, Mya arenaria, in response to eutrophic-driven changes in food 
supply and habitat. Journal of Experimental Marine Biology and Ecology 313: 75-104.

Castagna, M. \& P. Chanley. 1973. Salinity tolerance of some bivalves from inshore and estuarine environments in Virginia waters on the western mid-atlantic coast. Malacologia 12 (1): 47-96.

Chanley, P. \& M. Castagna. 1971. Larval development of the stout razor clam, Tagelus plebeius Solander (Solecurtidae: Bivalvia). Cheseapeake Science 12 (3): 167-172.

Clasing, E.; T. Brey; R. Stead; J. Navarro \& G. Asencio. 1994. Population dynamics of Venus antiqua (Bivalvia: Veneracea) in the Bahía de Yaldad, Isla de Chiloé, southern Chile. Journal of Experimental Marine Biology and Ecology 177: 171-186.

CraIG, N.I. 1994. Growth of the bivalve Nucula annulata in nutrient-enriched environmets. Marine Ecology Progress Series 104: 77-90.

CRISP, D.J. 1984. Energy flow measurements, p. 284-372. In: N.A. Holme \& A.D. MCInTYre (Eds). Methods for the study of marine benthos. Rome, Blackwell Scientifics Pub., 387p.

Defeo, O. 1993. Reproduction of coastal invertebrates through the management on natural areas: a successful example. Out of the Shell 3: 11-13.

Defeo, O. 1998. Testing hypotheses on recruitment, growth and mortality in exploited bivalves: an experimental perspective. Canadian Special Publication of Fisheries and Aquatic Sciences 125: 257-264.

Defeo, O. \& A. DE Alava. 1995. Effects of human activities on long-term trends in sandy beach populations: the wedge clam Donax hanleyanus in Uruguay. Marine Ecology Progess Series 123: 73-82.

Defeo, O.; F. Arreguín-Sánchez \& J. SÁnchez. 1992. Growth study of the yellow clam Mesodesma mactroides: a comparative analysis of three length-based methods. Scientia Marina 56: 53-59.

Defeo. O; J. Gómez \& D. Lercari. 2001. Testing the swash exclusion hypothesis in sandy beach populations: the mole crab Emerita brasiliensis in Uruguay. Marine Ecology Progress Series 212: 159-170.

De Montaudouin, X. 1996. Factors involved in growth plasticity of cockles Cerastoderma edule (L.), identified by field survey and transplant experiments. Journal of Sea Research 36: 251-265.

EAGAR, R.M.C. 1978. Shape and function of the shell: A comparison of some living and fossil bivalve molluscs. Biological Review 53: 169-210.

FAHY, E. \& J. GaffNey. 2001. Growth statistics of an exploited razor clam (Ensis siliqua) bed at Gormanstown, Co Meath, Ireland. Hydrobiologia 465: 139-151.

Farinati, E.A.; S. Aliotta \& S.S. Ginsberg. 1992. Mass mortality of a Holocene Tagelus plebeius (Mollusca, Bivalvia) population in the Bahía Blanca Estuary, Argentina. Marine Geology 106: 301-308.

Fuiman, L.; J.D. Gage \& P.A. LAmONT. 1999. Shell morphometry of the deep sea protobranch bivalve Ladella pustulosa in the Rockall Though, North-East Atlantic. Journal of the Marine Biological Association of the United Kingdom 79: 661-671.

Gaspar, M.B.; C.A. Richardson \& C.C. Monteiro. 1994. The effects of dredging on shell formation in the razor clam Ensis siliqua from Barrinha, Southern Portugal. Journal of the Marine Biological Association of the United Kingdom 74: 927938.

Gaspar, M.B.; M.N. SANTOS \& P. VASCONCELOS. 2001. Weight-length relationships of 25 bivalve species (Mollusca: Bivalvia) form the Algarve coast (southern Portugal). Journal of the Marine Biological Association of the United Kingdom 81: 805807.

Gaspar, M.B.; M.N. Santos; P. Vasconcelos \& C.C. Monteiro. 2002. Shell morphometric relationships of the most common bivalve species (Mollusca, Bivalvia) of the Algarve coast (southern Portugal). Hydrobiologia 477: 73-80.

Gayanilo, F.C.; P. Sparre \& D. Pauly. 1996. The FAO-IClarm Stock Assessment Tools (FISAT) user's guide. Rome, FAO Computerized Information Series (Fisheries) 8, 126p.

GilLmor, R.B. 1982. Assessment of intertidal growth and capacity adaptations in suspension-feeding bivalves. Marine Biology 68: $277-286$.

Gómez, J. \& O. Defeo. 1999. Life history of the sandhopper Pseudorchestoidea brasiliensis (Amphipoda) in sandy beaches with contrasting morphodynamics. Marine Ecology Progress Series 182: 209-220.

Grant, J. \& G. Daborn. 1994. Effects of bioturbation on sediment transport in an intertidal mudflat. Netherlands Journal of Sea Research 32: 63-73.

Guevara, J.M. \& F.X. Niell. 1989. Growth rates in a continuously immersed population of Cerastoderma edule L. Scientia Marina 53: 483-489.

Gutiérrez, J.L.; M.G. Palomo \& O.O. Iribarne. 2004. Environmental heterogeneity and species responses to fishing disturbance: are the effects of clam harvesting spatially consistent? Fisheries Research 67: 55-70.

Henderson, S.M. \& C.A. Richardson. 1994. A comparison of the age, growth rate and burrowing behaviour of the razor clams, Ensis siquila and E. ensis. Journal of the Marine Biological Association of the United Kingdom 74: 939-954.

Нibвert, C.J. 1976. Biomass and production of a bivalve community on an intertidal mud-flat. Journal of Experimental Marine Biology and Ecology 25: 249-261.

Holland, A.F. \& J.M. Dean. 1977a. The biology of the stout razor clam Tagelus plebeius: I. Animal-sediment relationships, feeeding mechanism, and community biology. Cheseapeake Science 18 (1): 58-66.

Holland, A.F. \& J.M. Dean. 1977b. The biology of the stout razor clam Tagelus plebeius: II. Some aspects of the population dynamics. Cheseapeake Science 18 (2): 188-196.

Honkoop, P.J.C. \& J.J. Beukema. 1997. Loss of body mass in winter in three intertidal bivalve species: an experimental and 
observational study of the interacting effects between water temperature, feeding time and feeding behaviour. Journal of Experimental Marine Biology and Ecology 212: 277-297.

IrIBARNE, O. \& F. BotTo. 1998. Orientation of the stout razor clam Tagelus plebeius in relation to current direction: its paleoecological implication. Journal of Shellfish Research 17: 165-178.

Iribarne, O.; J. Valero; M.M. Martinez; L. Lucifora \& S. Bachmann. 1998. Shorebird predation may explain the origin of Holocene beds of stout razor clams in life position. Marine Ecology Progress Series 167: 301-306.

Lardies, M.A.; E. Clasing; J.M. Navarro \& R.A. Stead. 2001. Effects of environmental variables on burial depth of two infaunal bivalves inhabiting a tidal flat in southern Chile. Journal of the Marine Biological Association of the United Kingdom 81: 809-816.

Laudien, J.; T. Brey \& W.E. Arntz. 2003. Population structure, growth and production of the surf clam Donax serra (Bivalvia, Donacidae) on Namibian two sandy beaches. Estuarine, Coastal and Shelf Science 58S: 105-115.

Lima, M.; A. Brazeiro \& O. Defeo. 2000. Population dynamics of the yellow clam Mesodesma mactroides: recruitment variability, density-dependence and stochastic processes. Marine Ecology Progress Series 207: 97-108.

Lomovaski, J.B., A.M. Casariego, T. Brey \& O. Iribarne. 2006. The effect of the SW Atlantic burrowing crab Chasmagnathus granulatus on the intertidal razor clam Tagelus plebeius. Journal of Experimental Marine Biology and Ecology 337: 19-29.

Navarro, J.M.; G.E. Leiva; G. Martinez \& C. Aguilera. 2000. Interactive effects of diet and temperature on the scope for growth of the scallop Argopecten purpuratus during reproductive conditioning. Journal of Experimental Marine Biology and Ecology 247: 67-83.

Newell, C.R. \& H. Hidu. 1982. The effect of sediment type on growth rate and shell allometry in the soft-shelled Mya arenaria L. Journal of Experimental Marine Biology and Ecology 65: 285-295.

Ólafsson, E.; R. Elmgren \& O. Papakosta. 1993. Effects of the deposit-feeding benthic bivalve Macoma balthica on meiobenthos. Marine Biology 93: 457-462.

Omena, E.P. \& A.C.Z. Amaral. 1997. Distribuição espacial de polychaeta (Annelida) em diferentes ambientes entremarés de São Sebastião (SP). Oecologia Brasiliensis 3: 183-196.

Omena, E.P. \& A.C.Z. Amaral. 2000. Population dynamics and secondary production of Laeonereis acuta (Treadwell, 1923) (Nereididae: Polychaeta). Bulletin of Marine Science 67 (1): 421-431.

Paterson, K.J.; M.J. Schreider \& K.D. Zimmermman. 2003. Anthropogenic effects on seston quality and quantity and the growth and survival of Sidney rock oyster (Saccostrea glomerata) in two estuaries in NSW, Australia. Aquaculture
221: 407-426.

Pauly, D. \& J.L. Munro. 1984. Once more on the comparison of growth in fish and invertebrates. Fishbyte 2:21.

Pauly, D.; J. Moreau \& N. Abad. 1995. Comparision of age structure and lenght-converted catch curves of brown trout Salmo trutta in two french rivers. Fisheries Research 22: 197-204.

Peterson, C.H. \& R. BLACK. 1988. Response of growth to elevation fail to explain vertical zonation of suspension-feeding bivalves on a tidal flat. Oecologia 76: 423-429.

Rıos, E.C. 1994. Seashells of Brazil. Rio Grande, Fundação Universidade do Rio Grande, $2^{\text {nd }}$ ed., 492p.

Roseberry, L.; B. Vicent \& C. Lemaire. 1991. Growth and reproduction of Mya arenaria in their intertidal zone of the Saint Lawrence estuary. Canadian Journal of Zoology 69: 724-732.

Sheridan, P.F. \& R.J. Livingston. 1983. Abundance and seasonality of infauna and epifauna inhabiting a Halodule wrightii meadow in Apalachicola Bay, Florida. Estuaries 6 (4): 407-419.

Stanley, S.M. 1970. Relation of shell form to life habits in the Bivalvia. Geological Society of America Memmorials 125: $1-296$.

Trueman, E.R. 1966. Bivalve molluscs: fluid dynamics of burrowing. Science 152: 523-525.

Urban, H-J. 1994. Adaptations of six infaunal bivalves species of Chile: coexistence resulting from differences in morphology, burrowing depth and substrate preference. Archive of Fishery and Marine Research 42 (2): 183-193.

Urban, H-J. 1996. Population dynamics of the bivalves Venus antiqua, Tagelus dombeii, and Ensis macha from Chile at $36^{\circ}$ S'. Journal of Shellfish Research 15 (3): 719-727.

Urban, H-J. \& B. Campos. 1994. Population dynamics of the bivalves Gari solida, Semele solida and Protothaca thaca from a small bay in Chile at $36^{\circ} \mathrm{S}$. Marine Ecology Progress Series 115: 93-102.

Urban, H-J. \& J. Tarazona. 1996. Effects of El Niño/Southern oscillation on the population dynamics of a Gari solida population (Bivalvia, Psammobiidae) from Bahía Independencia, Peru. Marine Biology 125: 725-734.

UNDERWOOD, A.J. 1997. Experiments in ecology: their logical design and interpretation using analysis of variance. Cambridge University Press, 499p.

VAKILY, J.M. 1992. Determination and comparison of bivalve growth, with emphasis on Thailand and other tropics. Internacional Center for Living Aquatic Resources Management, Manila, Philippines, ICLARM Technical Report, 36, 125p.

VIÉGAS, O. 1982. Crescimento e produção de Tagelus plebeius (Solecurtidae: Bivalvia) no Canal do Calunga, Maceió, Alagoas. Atlântica 5 (2): 124-125.

ZAR, J.H. 1996. Biostatistical Analysis. New Jersey, Prentice Hall, $3^{\text {rd }}, 718 \mathrm{p}$.

Submitted: 14.V.2009; Accepted: 23.I.2010.

Editorial responsibility: Maria Lúcia Negreiros-Fransozo

ZOOLOGIA 27 (1): 54-64, February, 2010 